\title{
Digging into Downstairs: Exhibiting Domestic Service
}

\author{
Hanne Østhus*, Ulrike Spring**1
}

\begin{abstract}
This article is a case study of a newly opened exhibition at one of the most significant lieux de mémoire in Norway, the historic house museum Eidsvoll House. Eidsvoll House has, since 1814, played a key role in Norwegian stateand nation-building narratives and continues to do so today. The article explores the tenacity of national narratives by investigating the role museums play in contemporary nation-building processes. It particularly looks at attempts to integrate domestic servants into this dominant and controlling narrative, and investigates the complex relationship between social history, national narratives and museum communication strategies. It problematizes the exhibition strategy, popular at historic houses, of recreating the past at a specific juncture of time and argues that such an approach might help to reaffirm social hierarchies. On a more general level, the article aims to contribute to a productive exchange between academic and museum approaches to history.
\end{abstract}

Key words: domestic servants, exhibition analysis, nation-building, anniversary celebrations, historic houses, social class

\section{Introduction}

This article is a discussion of a newly opened exhibition at one of the most significant lieux de mémoire (Nora, ed. 1984-1992) in Norway. It highlights on a more general level the complex relationship between social history and national narratives and contributes to reflections on the ongoing role of museums in nation building-processes (Aronsson and Elgenius 2015; Bohman 1997; Thomas, ed. 2010). While such considerations might have seemed less relevant just 15 years ago, when discussions of a postnational society were more topical (cf. Habermas 2001), recent years have seen a new surge of academic interest in various forms of nationalism in Europe (Gould and Messina, ed. 2014). These new articulations of nationalism that researchers observe in contemporary societies, go hand in hand with what Michael Billig (1995) has called 'banal nationalism', that is everyday nationalism in particular in 'the West', which does not need to be openly announced or 'flagged', because it is an integral part of the citizens' self-understanding. As Billig (1995: 8) aptly describes it: 'The metonymic image of banal nationalism is not a flag which is being consciously waved with fervent passion; it is the flag hanging unnoticed on the public building.' All the more important for today's museums to understand, investigate and question their own role in these ongoing processes of producing and reaffirming national identity.

In this article we also wish to critically examine a display form that is common to historic houses and biographical museums and popular in Scandinavia (Sandberg 2003), that of freezing time to a specific juncture in history through diorama-like exhibitions. We will argue that while this way of exhibiting the past may open a unique window into history and provide a fascinating insight into everyday life, at the same time it denies change and continuity, which are crucial aspects of understanding the past.

The historic Eidsvoll House, about $60 \mathrm{~km}$ north of Oslo, has a special place in Norwegian history because it is where the Norwegian constitution was written in May 1814. On the occasion of the bicentenary celebration of that event in 2014, Eidsvoll House was renovated, 
including the complete restoration of the cellars with the servants' quarters. We argue that while this renovation does add a necessary and so far neglected perspective to the story of 1814 , it also contributes to bolstering a dominant, controlling national narrative, according to which the emergence of the Norwegian nation coincided with a history of democratization that started with the signing of the constitution in 1814. Moreover, it tends to reproduce a version of history in which the elites are active agents, while the lower classes are mainly supporting actors. As we will show, including servants in an exhibition narrative might not only lead to challenging established social hierarchies, but also to reinforcing them.

Historic houses, such as Eidsvoll House, are among the most common and accessible heritage sites worldwide (Hodge and Beranek 2011: 98-9). As such, they play an important role in shaping our ideas about the past. There is little critical scholarship on historic house museums in Norway, but scholarship on similar museums in America has pointed out how this type of heritage site has 'a long history of memorializing the economic and political activity of wealthy white men' (West 2003: 83). The current trend is to change this by seeking to include both women and workers in the narrative, an effort that in many historic house museums translates into including domestic servants - a group that is always workers and often women - into the exhibition (Donnelly, ed. 2002; Diethorn 2003; West 2003). Despite such efforts, it has been argued that conflicts between employers and servants are mostly overlooked or remain unmentioned in favour of an idealised, sanitised version of the past (Pustz 2010). This article deals with a historic house museum in Norway, a country where the discourses on race and class are less ideologically charged compared to the USA, but we argue that nonetheless class antagonism is downplayed in favour of an idea of national consensus. A similar critique has been levied at the English country house as a heritage site promoting and legitimizing a particular view of history in which the country house owners are given a prominent role in national history (for a review of this literature, see Smith 2006: 115-7, 119-22). What is particular with Eidsvoll House as compared to many other stately homes is that it is not only promoted as the home of a rich man or an aristocratic family who are given a leading role in the national narrative, but that it also is inserted into a dominant national narrative that focuses on the particular act, and the house as the birthplace of the democratic and modern Norwegian nation-state. This also means that the emphasis is not on the idea of continuity, as with many other stately homes (Smith 2014: 51), but on change, and particularly on the year 1814 as an important rupture in the history of Norway. Despite these differences, we argue, Eidsvoll House has similar issues to other stately homes who focus on their elite inhabitants when it comes to portraying non-elite inhabitants, particularly servants.

As historians, we are particularly interested in the stories that are told in the exhibition and in attending material, how they are aesthetically presented and inserted into existing historical narratives (Thiemeyer 2010:74-5). We wish to investigate more closely the intersection between academic and museum history and to contribute to a productive exchange between these two forms of history-telling. We consider this particularly important in a time where there are growing demands to 'apply' academic knowledge to wider contexts, in other words, to make it more 'useful'. On the other hand, cultural history museums have increasingly moved away from traditional disciplinary knowledge conveyed by historians and ethnographers and endorsed a focus on education and visitor studies (for a general perspective on this trend see Hooper-Greenhill 2007); many history museums today have to balance requests for edutainment and infotainment with correct historical representation. The challenge for the future is how to productively combine these two approaches again, something this article wishes to contribute to.

As part of our research, we spent a day at Eidsvoll House in June 2014 and participated in two guided tours of the main building: a private one through the newly refurbished cellars, conducted by one of the museum guides, and a public tour of the house in Norwegian together with other visitors. The public tour we took started in a room adjacent to the main entrance, and continued through the ground floor and the first floor before the guide led us to the cellar with the kitchen and the servant quarters. During our private tour we were given access to a larger part of the cellars than that which the average visitor enjoys on their visit. We were also given additional information about renovation details and could spend longer in the cellars than the average visitor, although we were not allowed to explore on our own on this tour either. 


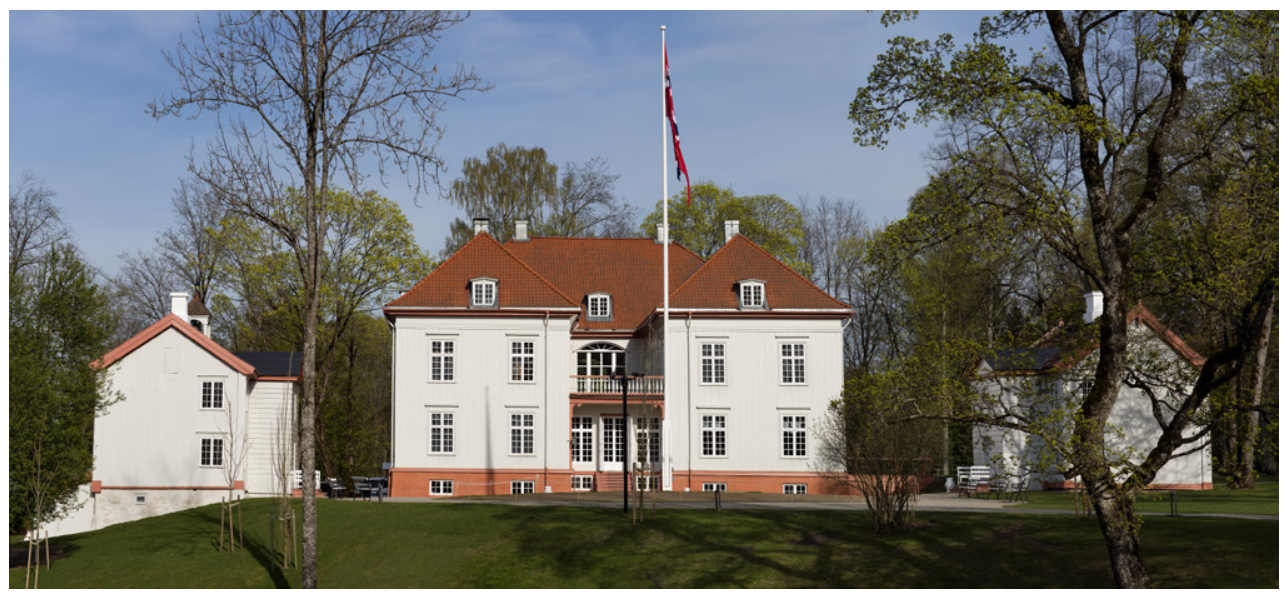

Figure 1: Eidsvoll House. Photograph: Statsbygg. Trond A. Isaksen.

For all visitors, the only access to the exhibition is through guided tours, and both the public and the private tour we were on were structured and planned by the museum. There are no explanatory texts in the exhibition, meaning that the artefacts, the house and the guides are the ones providing the visitor with the necessary historical knowledge. While this makes it easy to enter into a dialogue with the guides and to profit from their knowledge, at the same time the limited time one can spend in the house restricts the possibilities the visitor has for engaging with the exhibition and the objects on an individual basis and limits the number of narratives available on 1814.

Amy E. Potter (2016) has shown, through her work with tour guides in Louisiana plantation homes, that tours can vary substantially from tour guide to tour guide. We, therefore, do not, as Potter warns against, count our particular public tour as representative of all public tours, or even of all tours given by our particular tour guide. While our main focus is on our own reading of the exhibition narratives told through artefacts, atmosphere and accompanying texts in brochures, the guides' stories provided us with important historical background knowledge and helped us to position the displayed objects in a greater cultural, political and social context. In our reading of the exhibition we were inspired by the concept of double hermeneutics (Giddens 1976), in which the researcher investigates the subject's interpretation. We consider the exhibition as our main actor or subject, with the guided tours and explanatory material being an integrated part of it. This approach, combined with the main method of the historian, source criticism, made it possible to critically analyse historical representations and underlying power structures in the exhibition.

\section{Eidsvoll 1814 and Eidsvoll House}

In connection with the bicentenary of the Norwegian constitution in 2014, the Norwegian Parliament allocated over 384 million Norwegian kroner - around £38 million - to a full-scale renovation of Eidsvoll House, ${ }^{2}$ which makes it the most comprehensive restoration project in the Nordic countries today (Statsbygg, Eidsvoll 1814 and Grunnlovsjubileet, eds 2014a: 3 ). The main focus on the place as the space where the Norwegian constitution was written is also explicit in the written material available to visitors to the house: 'Eidsvoll House is a monument to the Norwegian constitution (...)', as a hand-out for English-speaking visitors plainly puts it (Eidsvoll 1814, ed). This is part of a tradition that stretches back to the first half of the nineteenth century: after the owner died heavily indebted in 1822, the house went to English creditors, but in 1837 a group of nationally-minded individuals interested in the events of 1814 collected enough money to buy the house, and Eidsvoll House became the first national monument in Norway (Risåsen 2005: 218-9). Since then, the history of the house as a late eighteenth-century patrician home and an iron works has been repressed in favour 
of the events of 1814 , or rather, six weeks in the spring of 1814. During that time, 112 men worked on a constitution, which was passed on 17 May, a day that is seen as so important that it has become the national day in Norway. The new constitution replaced absolutism with a constitutional monarchy and granted the right to vote to around $40 \%$ of men over 25 years of age, thereby laying the foundations for a future democratic state. With some minor revision, this constitution has also continued to be the founding document for the practice and division of power in Norway until today. The physical space the May constitution was written in - Eidsvoll House - has come to represent the narratives associated with 1814 and the development of the Norwegian nation. This identification between history and space is reflected in the use of the place name Eidsvoll, which has become shorthand for the constituent assembly of 1814 .

The connection between the house and the May constitution of 1814 is also evident in the restoration regime; renovations of Eidsvoll House have always coincided with celebrations of 1814: The first renovation was in 1864, on the 50 year anniversary of the constitution, and subsequent renovations have been carried out every 50 years since. ${ }^{3} \mathrm{~A}$ common factor in the renovations was that the custodians opted to implement recreation or restoration strategies rather than approaches based on continuity or on no restoration at all (Dahl 2009). ${ }^{4}$ In this latest renovation, leading up to the celebration in 2014, the ideal of creating an authentic image of 1814 was still the guiding principle; the brochure dealing with the restoration process states that '[t]he aim has been to make the building appear as it did in 1814' (Statsbygg, Eidsvoll 1814 and Grunnlovsjubileet, eds 2014b: 3). ${ }^{5}$ This attempt at freezing history at a specific point in time is also transmitted through the name of the building: In 1998, the museum changed its name to 'Eidsvoll 1814 '. ${ }^{6}$

However, reducing history to those six weeks in 1814 was not the only solution the restorers discussed prior to the latest restoration scheme. They also considered keeping much of what had been done during the last restoration in 1964, thus stressing the history of the house as museum. In 2005, for example, Geir Thomas Risåsen, current curator of the Eidsvoll House, discussed different options and reasoned that to recreate the house as it had been in 1814 would be to violate dominating principles of restoration which dictate that one should not remove traces of change and alteration. Despite this, Risåsen continued, one might still choose to recreate the house as it had been in 1814. Risåsen gave three reasons to explain why such a choice might be an option: firstly, he argued, much of the alterations and changes that would be removed were implemented after Eidsvoll House stopped being used as a residence; secondly, later restoration projects all aimed at recreating the situation in 1814; and thirdly, because of the extensive knowledge available regarding the residence, Eidsvoll might be a unique chance to recreate a house of the early 1800s (Risåsen 2005: 242). Such arguments must have been convincing because the restorers did choose to return the house to what it had looked like in 1814, thus preferring a focus on a specific juncture in time over continuity.

\section{Exhibiting servant culture}

In this latest restoration project, major work has been done in the cellars on the servant quarters. The cellars had been filled with soil in the 1860s in what was an attempt to stabilize the building, and history has thus literally been dug out of oblivion in recent years. The cellar is big -620 $\mathrm{m}^{2}$ - and is made up of the kitchen, pantry and wine cellar, food storage, the servants' hall, and four servants' rooms. Except for the food storage, all rooms have been restored to resemble what they looked like in 1814. The outreach programme of the museum places a major focus on these quarters, and tours often include visits to the cellars. ${ }^{7}$

The substantial amount of money and time spent on making the history of the servants at Eidsvoll House visible is part a larger international trend, where a focus on the lives of the working people, and particularly servants, has become a major topic in a number of museum exhibitions, for example at the Museum of Edinburgh and the Driehaus Museum in Chicago. ${ }^{8}$ One reason that has been given for the recent popular interest in servants is the economic downturn and financial uncertainty that followed the 2008 financial crash. When explaining the popularity of Downton Abbey, a journalist in The Guardian contended that the TV-show had 'captured the spirit of our own times: it portrays, in microcosm, a society on the brink of disaster'. ${ }^{9}$ Others have argued that the lives of servants have become 'relatable' (Ende 2013). 
For many people in contemporary society a life of work seems more plausible than a life lived in luxury. The academic interest in servants, on the other hand, is older, and in particular stems from a reorientation within the historical discipline from the 1970s onwards through which the focus shifted from kings, emperors and other 'famous men' to ordinary people. This meant that groups that had previously been overlooked, such as minorities, workers, women and also domestic servants, became research topics and museum subjects (e.g. Dubrow and Goodman, eds 2003; Dicks 2008).

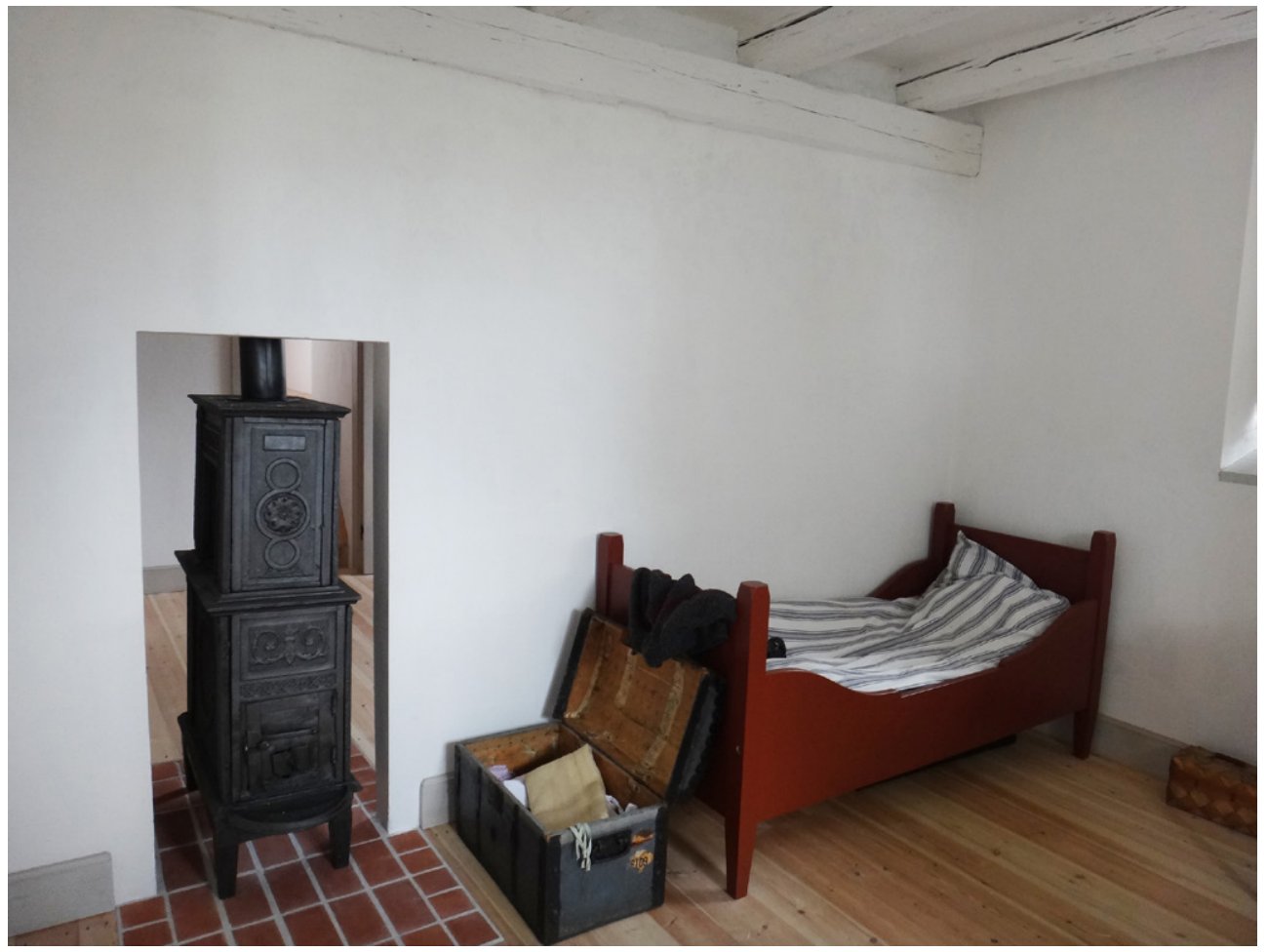

Figure 2: Servant's room. Eidsvoll House 2014. Photograph: Private.

Integrating servant culture into museum exhibitions allows us, as Laurajane Smith has urged in connection with English historic houses, to give agency to 'others' not just elites, and 'to engage in an active remembering of the lives and experiences of all the people who called these places home' (Smith 2014: 55). Eidsvoll House shares a comparable ambition: according to an English hand-out summarizing the history of the house, Eidsvoll House 'provides an important window into what life was like in 1814, both upstairs and downstairs' (Eidsvoll 1814, ed, handout to visitors, our emphasis), but apart from the name of the housekeeper and a valet little is known of the servants who worked at Eidsvoll House at the exact time when the constitution was written in 1814. In this, Eidsvoll House is not alone; other historic house museums have struggled with a similar lack of available information on the servants who worked there (Diethorn 2003). At Eidsvoll House, we found that the curators had dealt with this by choosing different communication strategies for the servants and the elites. The greatest difference is that the men upstairs are placed into a context of factual history, whereas the representation of the servants is bordering on fiction. This strategy was anticipated in Atle Næss' children's book / Grunnlovens hus. En bok om prinser og tjenestejenter, riksforsamlingen og 17. mai (In the house of the constitution. A book about princes and servant girls, the constituent assembly and 17 May) published in 2013 and written in cooperation with Eidsvoll House. While the main protagonists were people who have lived - a prince, the Eidsvoll men and the daughter of an iron worker 
-, a fictional aspect was added to the girl's biography by making her a servant girl at Eidsvoll House. In both cases, in the book and at Eidsvoll House, we have to imagine the lives of the servants and to picture the way they looked and worked; we are provided with partly fictitious stories. This strategy may be explained by the fact that the biographies of the men upstairs the members of the constituent assembly and the owner - are more or less known, whereas the lives of the servants below are, with few exceptions, unknown and accordingly have to be represented to the visitor in a shadow zone between historical facts and imagination. In Gayatri Chakravorty Spivak's words, this would mean that the men mostly are represented in the mode of vertreten - someone else assumes their voice but tries to echo their interests as closely as possible -, whereas the (mostly female) servants are re-presented as in darstellen - the images we have of them as generic persons are conflated with their actual existence (Spivak 1988). In both strategies someone else speaks for the protagonists, however, by situating the men upstairs within factual history, they keep their character as historical individuals, while the servants downstairs become clichés of what a servant should look like and behave as. This, we argue, risks reproducing a hierarchical structure of social class and serves to keep the servants outside or on the margins of the historically situated story of 1814 .

We met Eidsvoll's servants in three physical spaces: in the cellar with its kitchen and servant quarters, in back stairs and hidden corridors used by servants to navigate through the house and in one showcase exhibiting a pair of shoes in the nearby newly built 'Democracy centre'. The use the museum makes of these three spaces varies considerably but the commonality is that the servants remain outside the main narrative upstairs.

Let us have a closer look at those three spaces to illustrate our argument; the physical place where Eidsvoll's servants receive most attention is in the newly excavated and impressively restored cellar with the servant quarters. Some written historical evidence exists on how the rooms were furnished, ${ }^{10}$ but little furniture from this part of the house has survived. The curators chose to use new furniture for the servants' rooms in some cases. This was partly a consequence of the difficulty of getting everyday objects from the early nineteenth century, but as our guide told us on our private tour, this could also reflect the fact that the furniture had been fairly new in 1814 . While here the past was transferred into the present, with literally no time gap in-between, the colours applied to the furniture were based on recipes from 1814, something which leads to a mixing of the historical and the contemporary. As both a private house made public and a major monument in national memory, Eidsvoll conveys 'an imprimatur of authenticity' (Lowenthal 2008) to the things displayed and the space itself. The choice to leave the explanations of the servant quarters exclusively to the guides (and not to rely on, for example, additional texts) potentially leaves the idea of an authentic house of 1814 intact. The guide decides how much the visitor should know about the restoration process of the servant quarters. As a result, the mixing of past and present in the servants' quarters might become invisible to the visitor. The exhibition concept thus applies different meanings to authenticity on the various floors, with the downstairs interpretation being much more loosely linked to factual history, but at the same time conveying an impression of being historically authentic.

Finding the balance between historical facts and imagination, between academic history and a vivid image of the past is of course a common challenge for curators of history exhibitions. This has often been solved by inserting elements from 'living history' into exhibitions, by creating a 'docudrama' of the past (Mensch 2001: 52). This strategy was also applied at Eidsvoll House. On the public tour, a woman disguised as cook awaited us in the kitchen, telling us about servant life in spring 1814. While this truly formidable performance gave us a vivid image of the past, it at the same time inscribed itself in traditional tropes of how those downstairs should act. In her act, the cook took us back to those six weeks of 1814 when the influx of 112 elected representatives and the visit of a prince increased her workload substantially. She referred to this increased workload, but she also commented on the food served to the prince, remarking how odd it was. By doing so, the cook created a distance between herself and the prince, which - since she represents the servants - is a distance between those downstairs and those upstairs. It is, of course, possible and perhaps even plausible that the cook would react to unfamiliar food with a resigned comment, but since we know next to nothing of this particular cook we simply do not know what she would do, think or react to. This kind of representation creates the generic servant who is dargestellt and not vertreten. It also shows that the servants 


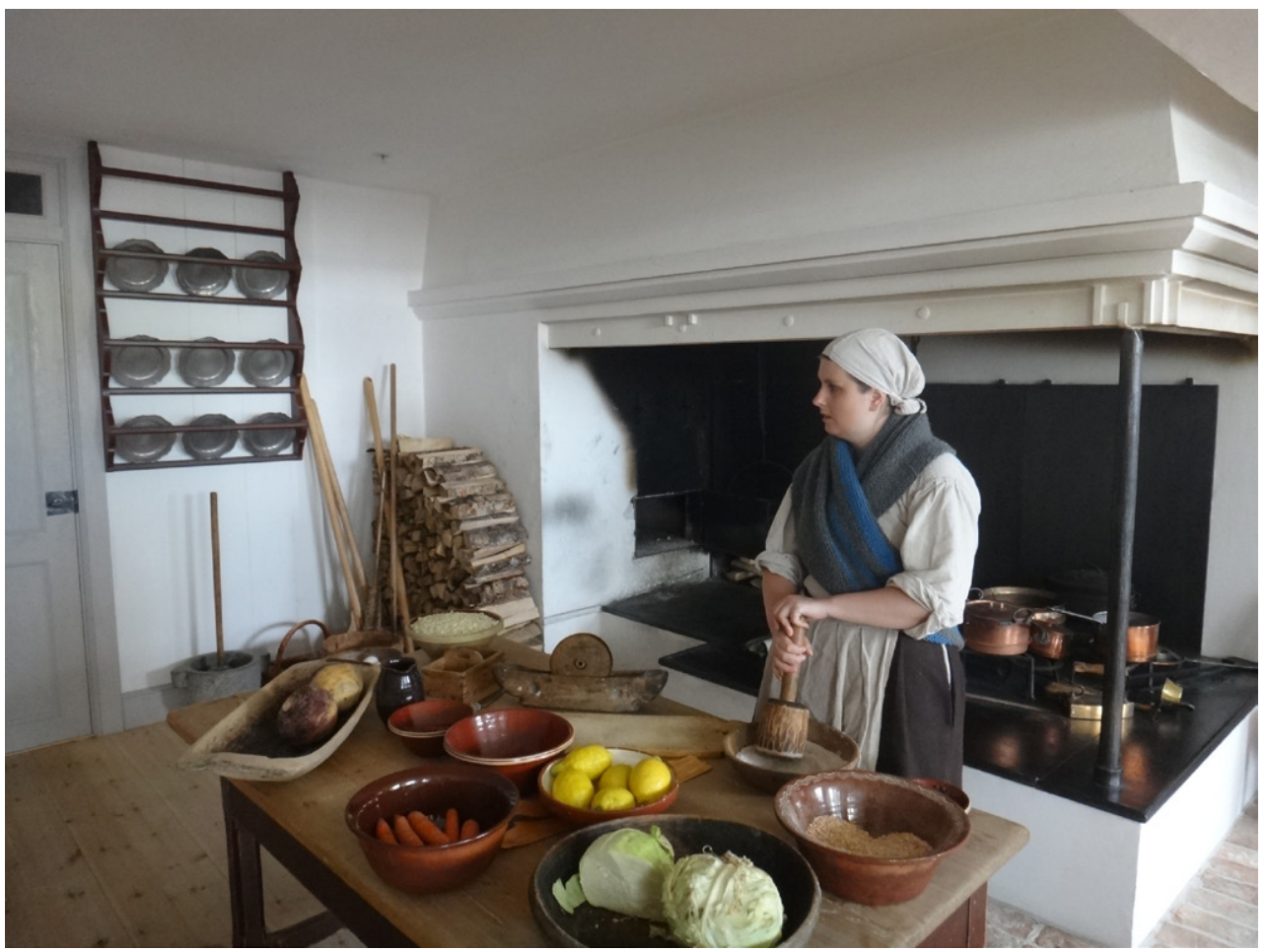

Figure 3: Kitchen with actress playing the cook. Eidsvoll House 2014. Photograph: Private.

are interpreted and positioned in relation to those upstairs. In contrast, the Eidsvoll men are mostly portrayed in relation to their fellow representatives or their respective home counties.

What the exhibition does accomplish with the excavation of the cellars is an exploration of everyday life. Here we can see how the cook uses her vacant hours to knit and sew, and the museum has used the kitchen to prepare meals that were served to the Eidsvoll men, who ate at the house. The museum has even experimented with how to make the most edible bark bread. The hearth in the kitchen is therefore no mere item to be exhibited. It is used, which again tells us just how much time and effort was spent on cooking at the beginning of the nineteenth century. Unfortunately, the hearth was not lit when we visited, precisely because of the time and effort it takes to light it and because of the heat and smoke it causes, thereby somewhat defeating the purpose of having a workable hearth. It could have been an interesting twist in the narrative to make this choice known to the visitors, as this would be a fine illustration of the hard working conditions nineteenth-century servants had to labour in.

The second space where we meet the servants are the hidden corridors and back stairs which connect upstairs and downstairs. These spaces were pointed out to us on our public tour, but might have much greater potential for use by the museum. These servant corridors were part of a large-scale modernization project the owner was undertaking in the Spring of 1814, and were constructed to limit the interaction between servants and their employers to a minimum by confining servants to hidden passages and back stairs (Risåsen 2005: 105-8). Systems of hidden corridors and back stairs were uncommon in Norway and this makes Eidsvoll House a rare source to a historian of domestic service. These corridors and stairs give an opportunity to contextualize the lives of the Eidsvoll servants by comparing them to servants both inside and outside Norway more generally. This is an important exercise in itself, as over 100,000 of Norway's near 900,000 inhabitants at the turn of the nineteenth century worked as servants (Norges offisielle statistikk 1980: 97-105). There also exists a large and growing scholarship 


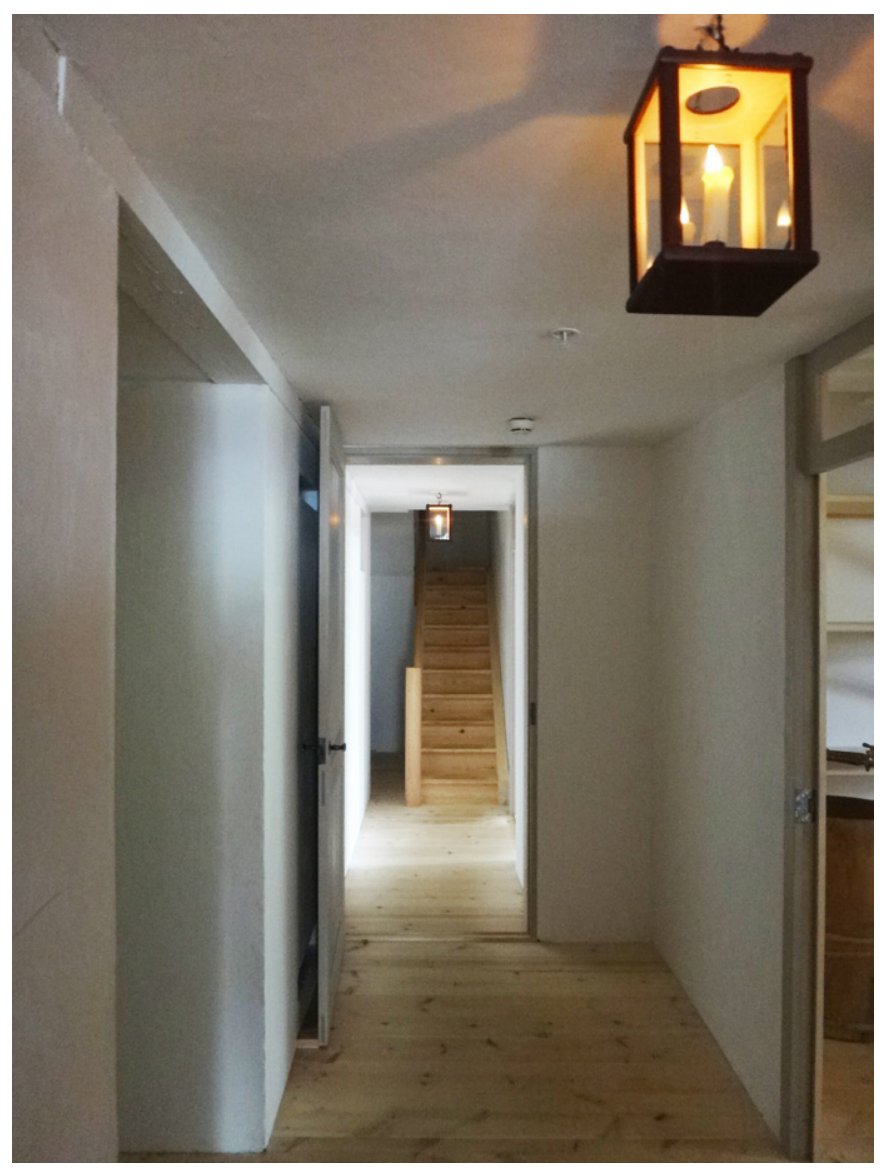

Figure 4: Hidden back stair between the servants quarters and upstairs. Eidsvoll House 2014. Photograph: Private. on domestic service in early modern Europe (Østhus 2013: 6-29). Situating the Eidsvoll servants within the wider context might at the same time help to counter their representation as generic or fictitious; by pointing out differences with other Norwegian servants in their everyday working life, they would gain more individual features. In other words, the servant becomes an object of mystery and speculation because the museum insists on focusing on 1814, not because there are no sources or literature available on servant life. ${ }^{11}$ Moreover, the corridors and hidden stairs present a narrative that differs from the ideal of social democratization usually associated with Eidsvoll House, and hence give the opportunity to adjust this dominant national narrative.

The third and last space which we would like to have a closer look at is placed outside Eidsvoll House, in the 'Democracy centre' that aims to bring the idea of democracy closer to young people. In a hall where

the paintings of many of the Eidsvoll men from 1814 are exhibited, there is a showcase with shoes from the early nineteenth century. As the information sheet informs us, these shoes belonged to a man who was said to have visited a servant maid at Eidsvoll House during the constituent assembly in 1814, but upon discovery fled, and in the commotion that followed forgot his shoes. This story is probably untrue; it thus serves mainly as an anecdote, covering over the harsh truth behind such sexual encounters in a time with strong social hierarchies and gender morals. Again, as in the examples outlined above, the servant is part of an at least partly fictive story, while the portraits surrounding the showcase situate the story of the men who participated in the constituent assembly in factual history.

\section{Making national narratives visible}

Our discussion of Eidsvoll House has to be understood within a larger perspective: the events at Eidsvoll House are celebrated each year as hundreds of thousands of Norwegians pour into the streets to commemorate the signing of the constitution on 17 May 1814. From public speeches held around the country on that day to newspaper articles and school textbooks, it is often the liberal elements of the constitution and the links to today's democracy that are emphasised. In its official policy document on the celebrations 2014, the Norwegian government stated that the anniversary should lead to more knowledge about the development of Norway as 
a democratic state ('Måldokument for Grunnlovsjubileet 2014'). Historical research conducted on the events of 1814 before and in connection with the bicentenary has explicitly challenged narratives of steady development and other established 'truths' of the events of 1814. It has done so by, among other things, changing the perspective from centre to periphery, taking a comparative and international approach, widening the timeframe and aiming to integrate groups that have been overlooked such as women and peasants (Bull and Maliks, eds 2014; Hemstad 2014; Hommerstad and Nordhagen, eds 2014, Hyvik et al., eds 2014; Nagel and Dyrvik, eds 2014). At the same time, the amount of resources used to research 1814 has paradoxically contributed to affirming the significance of this year in the national memory.

In addition, we can discern a continued tendency in popular media in Norway to link 1814 to ideas of social egalitarianism, national progression and historical continuity. One example is a feature published in April 2014 on the website of the tabloid VG, a popular Norwegian newspaper, (using research by Riksarkivet, The Genealogy Society of Norway (DIS-Norge) and Norsk lokalhistorisk institutt) where Norwegians could enter their last names in order to find out whether they were related to an 'Eidsvoll man'. This test quickly became very popular. ${ }^{12}$ In connection with this, people were asked to collect knowledge on the Eidsvoll men in a public database and help to trace their descendants. ${ }^{13}$

The test and the database convey the idea that everybody, regardless of her or his standing in society today, might be descended from the 'founding fathers' 14 of the nation. This goes hand in hand with a belief in a historical continuity from 1814, illustrated by the frequent use of the collective 'we' when talking about 1814. However, and this is a point we wish to make in this article, at the same time the test reproduced the social hierarchy hidden behind the notion of a democratic and egalitarian society: there was no test asking, 'Are you related to an Eidsvoll-servant?' While we may not speak of a 'structured amnesia' which Edwards and Mead (2013: 19) detect in Britain's dealings with its colonial past, there undoubtedly exists an asymmetry in the representation of these weeks in the media, leaning towards a heroic narrative of Norwegian democratic society and neglecting the less democratic aspects.

As Oskarsen (2012) shows, Eidsvoll House too promotes a dominant narrative of Eidsvoll as the starting point of Norwegian democratization processes. Moreover, in her analysis of outreach strategies aimed at school classes at Eidsvoll House in 2012, she shows that communicating national history and democracy are two sides of the same coin (Oskarsen 2012: 72). According to a policy paper from 2010, two of the main purposes of Eidsvoll House are to convey the story of what happened in 1814 and to foster interest in the challenges of democracy today (Galstad and Jondell 2010: 4). By including the servants, the new exhibition at Eidsvoll House aims at redressing the previous focus on the elite and to widen the perspective of 1814. This corresponds to the objective formulated by the museum itself, to 'work actively to create an interest in and commitment to the challenges democracy faces in our time, by making Eidsvoll 1814 visible and current' (Galstad and Jondell 2010: 4. Our translation). However, the interesting question is how liberal the constitution of 1814 was and how democratic the society that has followed its creation has been. No servant, for example, male or female, was given the right to vote in 1814. Also, as we have seen, the men who wrote the constitution did so in a house constructed to hide servants away and reduce their interaction with their masters and mistresses to a minimum. This was a costly and conscious effort to make the servants of the house invisible. Such a focus could add an interesting twist to the dominant narrative of Eidsvoll House as the cradle of Norwegian democracy. It might also highlight the differences the exhibition concept assigns to the servants and the elite men respectively, to make the different histories they are embedded in more explicit. As it is now, the men upstairs are, per se, part of the national and even global narrative of nation- and state-building, whereas the servants downstairs are exclusively linked to 1814. If they acquire national relevance, then it is in their role as symbols for the democratization of Norwegian society. The elite men of 1814 are thus part of 'real' history; they are active agents in history. The servants are supporting actors and mainly serve to illustrate and confirm the democratising process the men had set in motion; such a perspective risks downplaying the servants' significance for historical processes.

The way re-enactment was utilized on our public guided tour illustrates our argument regarding the use of these two different narratives of 'upstairs' and 'downstairs'. While we listened to and watched the cook performing in the kitchen, we were encouraged to re-enact 
factual history in the hall upstairs where the constitution had been signed. Here, the guide asked us to hold each other's hands and to repeat the Eidsvoll men's famous words from 200 years ago, which every pupil in Norway still knows: 'Enig og tro til Dovre faller' ('United and loyal until Dovre falls'). We literally embodied Norwegian national history, and through this act could affirm our belonging to a collective we, an 'imagined community' (Anderson 1991) which not only extends in space but also in time. Returning to Spivak's differentiation, we were asked to vertreten the men, assume their position and to insert ourselves into the larger historical narrative which they had helped to create. We might thus say that the representation form applied to the Eidsvoll men is based on mimesis, whereas the one used to exhibit the servants on mimicry. As Bhabha (1994: 127-8) reminds us, mimicry always implies a difference between the represented and the representer, despite efforts to make them indistinguishable. In this sense, the servants will be 'almost the same, but not quite', while the Eidsvoll men, through an uninterrupted historical line to today's Norwegians, will be 'the same'.

To counteract such an imbalance requires a more direct use of the language of social class, something which has been challenging to many heritage sites, not only Eidsvoll House (Dicks 2008). In a survey of visitors to English country houses, Laurajane Smith (2006: 146) found that class differences and 'uncomfortable history' were 'made comfortable through a sense of place'. Many of the visitors to the country house acknowledged class privilege, but accepted it because of the pride they felt when visiting beautiful country houses built by the upper classes. Only a minority, Smith reports (155), felt discomfort 'about the inequities between the social classes'. Eidsvoll House differs from the English country houses in Smith's survey because it is not primarily an elite family home on display, but most of the elements referred to by Smith's country house visitors can also be found at Eidsvoll House; the big house, the beautiful, clean and tidy grounds, the art and the grandeur. We would even argue that use of the language of class is even more necessary at Eidsvoll House because of the centrality of the notion of democracy there.

At Martin van Buren National Historic Site in Kinderhook, USA, Patricia West (2003) has both argued in favour of and given an example of how one can link a historic house and its residents to important changes at the time by way of the house's servants. Although the site's 'main' interpretative theme is 'Martin van Buren, president and statesman', West (2003: 90) argues that examining the Irish domestic servants who worked there

(...) is an ideal way of demonstrating some of the important changes in American political culture across Van Buren's lifetime, most significantly mass immigration, a feature of American history which has shaped its politics as well as its social structure in fundamental ways.

In a similar manner, the inclusion of servants in the dominant and controlling narrative at Eidsvoll House would enrich the notion of nineteenth-century democracy. It could even contribute to nuancing the concept of contemporary democracy, for instance by including references to the re-emergence of hired domestic help in today's society and thereby the possible emergence of a new lower class made up of underpaid immigrants, tasked with cleaning our houses and doing our laundry (Fauve-Chamoux 2004). In other words, Eidsvoll House, more than other historic houses because of its national significance, has the potential to open up to a reflective dispute and contestation of the various aspects and interpretations of democracy, starting with 1814 , by integrating uncomfortable historical facts, gaps in knowledge and in particular critical questions.

\section{Conclusion}

Bencard (2014: 36), drawing on the Dutch philosopher Eelco Runia, reminds us that the historical museum is 'a storehouse of discontinuity' despite its continuous efforts 'to create continuity'. Through its choice to focus on a few weeks in 1814, 'Eidsvoll 1814', or Eidsvoll House, is given an opportunity to display and tell discontinuous stories, to distance itself from a narration created in retrospect and instead to focus on the 'presence' (Runia) of 1814 and 2014 with their respective accompanying historical narratives. In the wake of postmodernist and poststructuralist debates, historians have become much more critical of History with a 
capital $\mathrm{H}$ and accept that there is a variation of perspectives from which history might be told. Eidsvoll House has incorporated such a perspective by adding the servants' history, but through its choice to reduce this history to a few weeks in 1814, at the same time tends to marginalize their relevance for the development of Norway. By telling two histories and by applying two different means of representation, the exhibition risks reproducing the established historical narrative of social hierarchies, of upstairs versus downstairs, rather than making these stories equal but different aspects of history. Considering its huge symbolic significance, Eidsvoll House cannot escape being part of, as well as partaking in, the story of the Norwegian nation evolving towards a democratic and egalitarian society throughout the centuries, but nonetheless it can turn this story into stories that compete with, contest and complement each other, adapting different meanings and opening up new interpretations.

While the relevance of Eidsvoll House for the Norwegian nation-building narrative is convincingly made explicit everywhere on its premises, we wish to advocate a meta-perspective on that history: the story that tells of how the constituent assembly held at Eidsvoll in 1814 came to be seen as the pivotal moment in Norwegian state- and nation-building. To paraphrase Billig (1995), we suggest to 'flag' national history more explicitly, to make the banalism, the everyday re-enactment of the nation, visible. Becoming aware of how we shape and create stories about ourselves as national citizens is crucial for a reflection on how we construct autoand heterostereotypes. Hence, the servant quarters do reflect much more than the events in 1814; indeed, they reflect the complex narrative of identity creation in Norwegian history.

While our focus here has been on this particular Norwegian narrative, the question of how to deal with nation-building narratives in the twenty-first century, with its challenges of cultural and social mobility and diversity, equally concerns museums in other countries. Moreover, this case study is also an investigation into and a reflection of how academic historians and museums represent social classes and their relevance in the past and present. Such exhibitions link to the situation of domestic workers today, and might open up for critical reflection the way class differences are more or less condoned in TV-series and museal representations by locating them safely in the past.

Received: 26 March 2015

Finally accepted: 24 October 2016

\section{Notes}

1 The article is the result of a co-operation between two historians, with one also having experience as a curator. We would like to thank the director and staff at 'Eidsvoll 1814' for their efficient and friendly help in providing photographs and answering questions. Many thanks also to three anonymous referees, Ruth Hemstad, Hilde Sandvik, Johan Schimanski and the participants at the historieseminar in Sogndal for their very useful comments on earlier drafts of this article.

2 Statsbygg, 'Eidsvollsbygningen. Rehabilitering'. http://www.statsbygg.no/Prosjekter-ogeiendommer/Byggeprosjekter/Eidsvollsbygningen/, accessed 15 December 2014.

3 Eidsvoll 1814 , 'Eidsvollsbygningen'.

http://www.eidsvoll1814.no/default.aspx?aid=9063381, accessed 20 September 2014.

4 Eidsvoll 1814, '1914 restaureringen'.

http://www.eidsvoll1814.no/default.aspx?aid=9070972, accessed 20 May 2014.

5 Our translation. 'Målet har vært å få bygningen til å framstå mest mulig slik den gjorde i 1814.'

6 In 1998, the name was 'Eidsvoll 1814-Rikspolitisk senter'. From 2003, the name has been simply 'Eidsvoll 1814'. 
7 Eidsvoll 1814, 'BesøkEidsvoll i2015', http://www.eidsvoll1814.no/default.aspx?aid=9060953, accessed 15 February 2016.

8 Edinburgh museum, http://www.edinburghmuseums.org.uk/Collections/Art-Collections/ Decorative-Art/Decoratve-Art-at-Lauriston-Castle/Upstairs-Downstairs; Driehaus museum, http://www.driehausmuseum.org/programs/view/help wanted the summer servants tour, accessed 9 September 2014.

9 Groskop, V. (2010), 'Downton Abbey Fans Brace for Farewell', The Guardian, 6 November

http://www.theguardian.com/tv-and-radio/2010/nov/06/downton-abbey-itv-last-episode, accessed 1 December 2014.

10 Eidsvoll 1814, '2014-restaureringen'. http://www.eidsvoll1814.no/?did=9071175, accessed 10 February 2016.

11 Curators at Eidsvoll House are currently working on obtaining more information on domestic servants, and it will be interesting to learn how they transform this knowledge into communication strategies.

12 K.H. Aanstad, 'Er du i slekt med en eidsvollsmann?' http://www.vg.no/rampelys/1814-2014/ er-du-i-slekt-med-en-eidsvollsmann/a/10138433/, accessed 9 July 2014.

13 'Eidsvollsmennenes etterkommere'. http://www.eidsvollsmenn.no/, accessed 24 February 2015.

14 The 'myth of foundation' marks a new beginning in the history of a state, conveying the message 'that afterwards everything will be different ("better") and that the newly founded system has dispensed with whatever made the old reprehensible' (Schöpflin 1997: 33).

\section{References}

Anderson, B. (1991) Imagined Communities: Reflections on the Origin and Spread of Nationalism, revised and extended ed. London: Verso.

Aronsson, P. and Elgenius, G. (2015) National Museums and Nation-Building in Europe 1750-2010: Mobilization and Legitimacy, Continuity and Change, London: Routledge.

Bencard, A. (2014) 'Presence in the Museum: On Metonymies, Discontinuity and History Without Stories', Museum \& Society, 12 (1) 29-43 https://www2.le.ac.uk/ departments/museumstudies/museumsociety/documents/volumes/bencard.pdf.

Bhabha, H.K. (1994) The Location of Culture, London and New York: Routledge.

Billig, M. (1995) Banal Nationalism, London: Sage Publications.

Bohman, S. (1997) Historia, museer och nationalism, Stockholm: Carlsson.

Bull, I. and Maliks, J. (eds) (2014) Riket og regionene. Grunnlovens regionale forutsetninger og konsekvenser, Trondheim: Akademika Forlag.

Dahl, S.T. (2009) 'Eidsvollsbygningens restaureringer til grunnlovsjubileene i 1914 og 1964, og disse sett i lys av ulike restaureringsprinsipper', MA thesis, University of Oslo.

Dicks, B. (2008) 'Performing the Hidden Injuries of Class in Coal-Mining Heritage', Sociology, 42 (3) 436-52. 
Diethorn, K. with Bacon, J. (2003) 'Domestic Work Portrayed: Philadelphia's Restored Bishop William White House - A Case Study', in Gail Lee Dubrow and Jennifer B. Goodman (eds) Restoring Women's History through Historic Preservation, 96-110, Baltimore and London: Johns Hopkins University Press.

Donnelly, J. F. (ed) (2002) Interpreting Historic House Museums, Walnut Creek, CA: AltaMira Press.

Dubrow, G.L. and Goodman, J.B. (eds) (2003) Restoring Women's History through Historic Preservation, Baltimore and London: Johns Hopkins University Press.

Edwards, E. and Mead, M. (2013) 'Absent Histories and Absent Images:

Photographs, Museums and the Colonial Past', Museum and Society, 11 (1) 19-38 http://www2.le.ac.uk/departments/museumstudies/museumsociety/documents/ volumes/edwardsmead.pdf.

Eidsvoll 1814 (ed) (n.d.) Eidsvollsbygningen (Eidsvoll House), hand-out to visitors.

Ende, R. (2013) 'The Rise of Downstairs', Colombia Daily Spectator, 14 (6), 6 March.

Fauve-Chamoux, A. (ed) (2004) Domestic Service and the Formation of European Identity: Understanding the Globalization of Domestic Work, $16^{\text {th }}-21^{\text {st }}$ Centuries, Bern: Peter Lang.

Galstad, A. and E. Jondell (2010) 'Målstyring og resultatoppnåelse', dated 22 April 2010, http://www.museumsforbundet.no/pdf/Malstyring Eidsvoll1814.pdf.

Giddens, A. (1976) New Rules of Sociological Method: A Positive Critique of Interpretative Sociologies, London: Macmillan.

Gould, A.C. and Messina, A.M. (eds) (2014) Europe's Contending Identities: Supranationalism, Ethnoregionalism, Religion, and New Nationalism, New York: Cambridge University Press.

Habermas, J. (2001) The Postnational Constellation: Political Essays, translated, edited, and with an introduction by Max Pensky, Cambridge, Mass.: MIT Press.

Hemstad, R. (2014) Propagandakrig: kampen om Norge i Norden og Europa 1812-1814, Oslo: Novus Forlag.

Hodge, C. J. and Beranek, C. M. (2011) 'Dwelling: Transforming Narratives at Historic House Museums', International Journal of Heritage Studies 17 (2): 97-101.

Hommerstad, M. and Nordhagen Ottosen, M. (eds) (2014) Ideal og realitet. 1814 i politisk praksis for folk og elite, Oslo: Akademika Forlag.

Hooper-Greenhill, E. (2007) Museums and Education: Purpose, Pedagogy, Performance, London and New York: Routledge.

Hyvik, J.J., Hoel, O.L. and Krøvel, H. (eds) (2014) Med påhalden penn? 1814 sett frå Nordvestlandet og Telemark, Oslo: Novus forlag.

Lowenthal, D. (2008) 'Authenticities Past and Present', CRM: The Journal of Heritage Stewardship 5 (1): 6-17 http://www.nps.gov/history/crmjournal/Winter2008/view.html.

'Måldokument for Grunnlovsjubileet 2014' https://www.stortinget.no/Global/pdf/ Grunnlovsjubileet/maaldokument grunnlovsjubileet.pdf, accessed 24 February 2015. 
Mensch, P. (2001) 'Tussen narratieve detaillering en authenticiteit. Dilemma's van een contextgeoriënteerde ethiek', Interieurs belicht, 46-55, Zwolle/Zeist: Waanders Uitgevers/Rijksdienst voor de Monumentenzorg.

Næss, A. (2013) I Grunnlovens hus. En bok om prinser og tjenestejenter, riksforsamlingen og 17. mai, Oslo: Gyldendal.

Nagel, A.H. and Dyrvik, S. (eds) (2014) Folkestyre? Kritisk lys på 1814-demokratiet, Bergen: Bodoni.

Nora, P. (ed) (1984-1992) Les Lieux de mémoire, Paris: Gallimard.

Norges offisielle statistikk (1980), Folketeljinga 1801- Ny bearbeiding, Oslo: Statistisk sentralbyrå.

Oskarsen, K. (2012) Demokrati - handling, arv og identitet: Demokratiformidling ved Eidsvoll 1814, MA thesis, University of Oslo https://www.duo.uio.no/bitstream/ handle/10852/24315/Oskarsen Master.pdf? sequence=1\&isAllowed=y

Østhus, H. (2013) Contested Authority. Master and Servant in Copenhagen and Christiania, 1750-1850, $\mathrm{PhD}$ thesis, European University Institute, Florence, Italy.

Potter, A.E. (2016) "'She Goes into Character as the Lady of the House": Tour Guides, Performance, and the Southern Plantation', Journal of Heritage Tourism 11 (3): 250-61, http://www.tandfonline.com/doi/full/10.1080/1743873X.2015.1100626.

Pustz, J. (2010) Voices from the Back Stairs: Interpreting Servants' Lives at Historic House Museums, DeKalb: Northern Illinois University PressRisåsen, G.T. (2005) Eidsvollsbygningen: Carsten Anker og Grunnlovens hus, Oslo: Damm.

Sandberg, M.B. (2003) Living Pictures, Missing Persons: Mannequins, Museums, and Modernity, Princeton and Oxford: Princeton University Press.

Schöpflin, G. (1997) 'The Functions of Myth and a Taxonomy of Myths', in Geoffrey Hosking and George Schöpflin (eds), Myths \& Nationhood, 19-35, London: Hurst \& Company.

Smith, L. (2006) Uses of Heritage, London and New York: Routledge.

(2014) 'Domestic Bliss or the Great Divide? Country Houses and the Perpetuation of Social Inequality', in Polly Harknett, Caitlin Heffernan and Matt Smith (eds), Unravelling Uppark, 48-55, Unravelled Arts Limited.

Spivak, G.C. (1988) 'Can the Subaltern Speak?', in Cary Nelson and Lawrence Grossberg (eds), Marxism and the Interpretation of Culture, 271-313, Urbana: University of Illinois Press.

Statsbygg, Eidsvoll 1814 and Grunnlovsjubileet 1814-2014 (eds) (2014a) Restaureringen av kjelleren. Eidsvollsbygningen 1814-2014, brochure for visitors.

Statsbygg, Eidsvoll 1814 and Grunnlovsjubileet 1814-2014 (eds) (2014b) Restaureringen av Rikssalen. Eidsvollsbygningen 1814-2014, brochure for visitors.

Thiemeyer, T. (2010) 'Geschichtswissenschaft: Das Museum als Quelle', in Joachim Baur (ed), Museumsanalyse. Methoden und Konturen eines neuen Forschungsfeldes, 73-94, Bielefeld: transcript Verlag.

Thomas, D. (ed) (2010) Museums in Postcolonial Europe, London: Routledge. 
West, P. (2003) 'Uncovering and Interpreting Women's History at Historic House Museums', in Gail Lee Dubrow and Jennifer B. Goodman (eds), Restoring Women's History through Historic Preservation, 83-95, Baltimore and London: Johns Hopkins University Press.

*Dr Hanne Østhus is Associate Professor of History at Sogn og Fjordane University College, Norway. She recently defended her PhD at the European University Institute in Florence, Italy. In her dissertation, she investigated the relationship between masters and domestic servants in two towns in Denmark-Norway between 1750 and 1850. She is particularly interested in relations of work, power and gender in the early modern period. Her most recent projects deal with the uses of space in the eighteenth century and methodological and theoretical challenges connected with digitalising history.

Faculty of Social Sciences

Sogn og Fjordane University College

Postboks 133

6851 Sogndal

Norway

Hanne.osthus@hisf.no

phone: +4799277632

fax: +4757676301

**Dr Ulrike Spring is Associate Professor of History at Sogn og Fjordane University College, Norway. She has earlier worked as curator at the Historical Museum of Vienna (Wien Museum) and has curated exhibitions on Viennese tavern culture, Mozart, Schubert and H.C. Andersen. Her main research interests are museology and cultural heritage, nationalism, travel cultures and (polar) expeditions. Recent publications include Formidling for framtida - tanker om arkiv (Dissemination for the Future - Reflections on Archives 2013, edited with Hilde Lange) and the monograph Passagiere des Eises: Polarhelden und arktische Diskurse 1874 (2015, with Johan Schimanski).

Faculty of Social Sciences

Sogn og Fjordane University College

Postboks 133, 6851 Sogndal

Norway

ulrike.spring@hisf.no

phone: +4741686300

fax: +4757676301 